\title{
ANALYSIS OF FRICTION AND LUBRICATION OF HUMAN JOINT'S SURFACES
}

\author{
Michat Sobociński \\ Institute of Mechanical Technology, Czestochowa University of Technology \\ Częstochowa, Poland \\ sobocinski@iop.pcz.pl
}

\begin{abstract}
The paper applies to the problem connected with analytical modeling of operational parameters of bio-bearings and endoprostheses. The mentioned model takes into consideration the influence of velocity and pressure on the value of the friction coefficient. It also presents the results of the tests conducted to define parameters of cooperation between different materials applied in implantology.
\end{abstract}

Keywords: friction, coefficient of friction, tribological model

\section{Introduction}

Proper lubrication of cooperating surfaces of both joint and endoprosthesis grants efficiency of limb movement and the patient's wellbeing. To prevent from over-wear in the joint slot, proper pressure and lift force distribution should be created.

Natural human joints are incredibly capable to self-regulate the joint slot's height, eccentric and extreme pressure additive. Synovial liquid can also be regulated, especially as far as lubricity and viscosity are concerned. Some specialists call bio-bearings an "intelligent bearing" $[1,2]$.

Analytical modeling of operational parameters of bio-bearings and endoprostheses requires the knowledge of hydromechanics of non-Newtonian liquids, mechanics of continuous medium, thermo-elasticity and hyper-elasticity.

Figure 1 presents the assumption that the spherical head of the hip joint can move rotationally in one or two directions.

The following markings were taken:

$\varphi$ - parallel coordinates (rotational),

$r$ - slot's height coordinates orthogonal to the sliding surface,

$\vartheta$ - meridional coordinates. 
a)

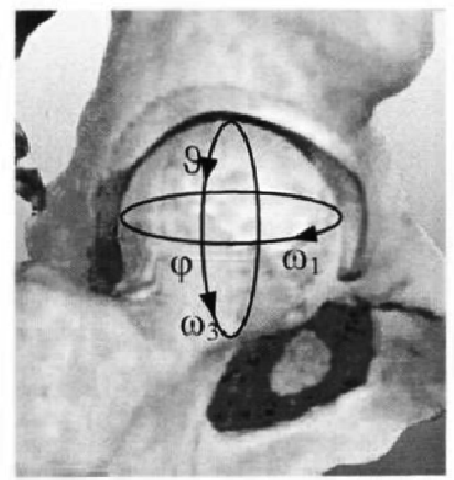

b)

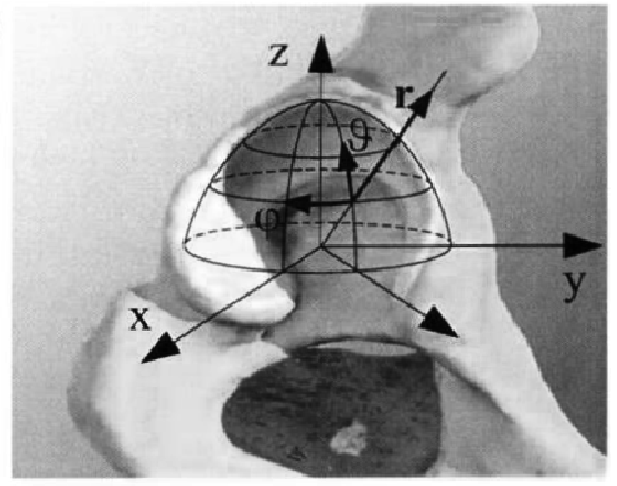

Fig. 1. Human hip joint: a) spherical head of femoral bone, b) cup [1]

The simplest way to present friction coefficient is:

$$
\mu=\frac{F}{C}
$$

where:

F - friction force,

C - lift force.

If the head turns in two directions

$$
\alpha_{1}=\varphi, \alpha_{3}=\vartheta,
$$

By taking into consideration the influence of velocity, pressure and magnetic field but without considering their common influence on the values of friction force, based on formula (1), the total value of friction coefficient is [1]:

$$
=\frac{\sqrt{\left(F_{R 1 \omega}+F_{R 1 p}+F_{R 1 M}+\Delta F_{R 1 \omega}+\Delta F_{R 1 p}+\Delta F_{R 1 M}\right)^{2}+\left(F_{R 3 \omega}+F_{R 3 p}+F_{R 3 M}+\Delta F_{R 3 \omega}+\Delta F_{R 3 p}+\Delta F_{R 3 M}\right)^{2}}}{\iint_{\Omega} p(\phi, \vartheta) d \Omega}
$$

Friction forces on the spherical head in parallel movement are:

$$
\begin{aligned}
\mu_{\varphi}= & \frac{F_{R \varphi \omega}+F_{R \varphi p}+F_{R \varphi M}+\Delta F_{R \varphi \omega}+\Delta F_{R \varphi p}+\Delta F_{R \varphi M}}{\iint_{\Omega} p(\phi, \vartheta) d \Omega} \\
\mu_{\vartheta}= & \frac{F_{R \varphi \omega}+F_{R \vartheta p}+F_{R \vartheta M}+\Delta F_{R \vartheta \omega}+\Delta F_{R \vartheta p}+\Delta F_{R \vartheta M}}{\iint_{\Omega} p(\phi, \vartheta) d \Omega}
\end{aligned}
$$

For the rotational movement of the spherical head bone in two directions, and considering the influence of velocity and pressure influence, the following values of friction coefficient in directions $\varphi$ and $\vartheta$ occur: 


$$
\begin{gathered}
\mu_{\varphi}=\frac{F_{R \varphi \omega}+F_{R \varphi p}}{\iint_{\Omega} p^{(o)} d \Omega} \\
\mu_{\vartheta}=\frac{F_{R \vartheta \omega}+F_{R \vartheta p}}{\iint_{\Omega} p^{(o)} d \Omega}
\end{gathered}
$$

In the case of steady rotational motion, the pressure is defined with the formula:

$$
\frac{1}{\sin \vartheta} \frac{\partial}{\partial \varphi}\left(\varepsilon_{1}^{3} \frac{\partial p_{10}}{\partial \varphi}\right)+\frac{\partial}{\partial \vartheta_{1}}\left(\varepsilon_{1}^{3} \frac{\partial p_{10}}{\partial \vartheta_{1}} \sin \vartheta_{1}\right)=6 \frac{\partial \varepsilon_{1}}{\partial \varphi} \sin \vartheta_{1}
$$

For dependance (4) and (5) we put the friction force formulas:

$$
\begin{gathered}
F_{R \varphi \omega}=\omega_{1} \eta_{0} R \iint_{\Omega} \frac{\sin \left(\frac{\vartheta}{R}\right)}{\varepsilon(\varphi, \vartheta)} d \Omega \\
F_{R \varphi p}=\frac{1}{2 R} \iint_{\Omega} \frac{\varepsilon(\varphi, \vartheta)}{\sin \left(\frac{\vartheta}{R}\right)} \frac{\partial p^{(o)}}{\partial \varphi} d \Omega \\
F_{R \vartheta \omega}=\omega_{3} \eta_{0} R \iint_{\Omega} \frac{\sin (\varphi)}{\varepsilon(\varphi, \vartheta)} d \Omega \\
F_{R \vartheta p}=\frac{1}{2} \iint_{\Omega} \varepsilon(\varphi, \vartheta) \frac{\partial p^{(o)}}{\partial \vartheta} d \Omega
\end{gathered}
$$

where:

$0 \leq \varphi=\alpha_{1} \leq a_{e}<2 \pi$,

$b_{m} \leq \vartheta=\alpha_{3} \leq b_{s}$.

We achieve the following values of friction coefficient occurring during steady lubrication of the spherical head's surface [1]:

$$
\begin{gathered}
=\frac{\omega_{1} \eta_{0} R \iint_{\Omega} \frac{\sin \left(\frac{\vartheta}{R}\right)}{\varepsilon} d \Omega+\frac{1}{2 R} \iint_{\Omega} \frac{\varepsilon}{\sin \left(\frac{\vartheta}{R}\right)} \frac{\partial p^{(o)}}{\partial \varphi} d \Omega}{\iint_{\Omega} p^{(o)} d \Omega} \\
\mu_{\vartheta}=\frac{\omega_{3} \eta_{0} R \iint_{\Omega} \frac{\sin (\varphi)}{\varepsilon} d \Omega+\frac{1}{2} \iint_{\Omega} \varepsilon \frac{\partial p^{(o)}}{\partial \vartheta} d \Omega}{\iint_{\Omega} p^{(o)} d \Omega}
\end{gathered}
$$




\section{Defining friction coefficient of hip joint endoprosthesis}

Endoprostheses durability, as well as possibility of complications, depend on friction - wear processes occurring in the contact area between the head and the cup. It is very important to be aware of the processes taking place in an artificial hip joint in conditions similar to the ones in the human body.

All the tests conducted on simulators considered cooperation between friction elements as far as movement kinematics and loads dynamics in the human body are concerned. The results apply mostly to friction and wear occurring in endoprosthesis, but also provide information about dynamic characteristics of the materials used to build the artificial joint [3-5].

The analysis conducted on hip joint simulator, also consisted of tests on cooperation between friction elements of endoprosthesis [6]. The friction node is presented in Figure 2.

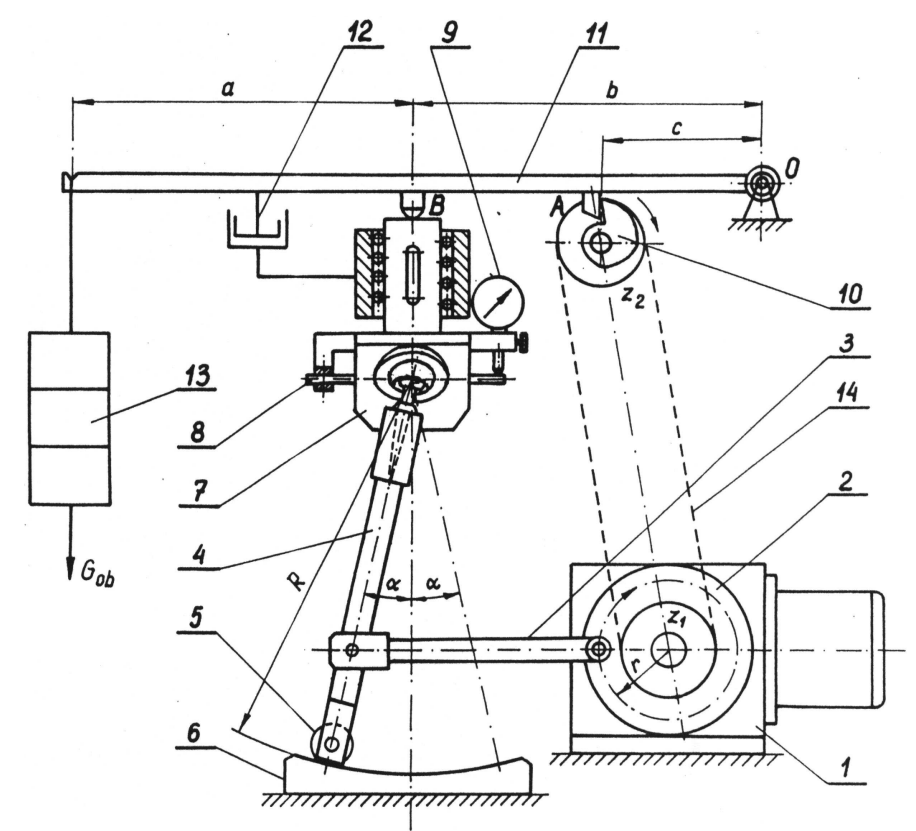

Fig. 2. Schematic diagram of the stand for testing durability of human hip joint endoprosthesis [7]

The tests were conducted with the following parameters:

- static load force $\mathrm{P}_{\mathrm{st}}=1200 \mathrm{~N}$,

- dynamic load $\mathrm{P}_{\mathrm{dyn}}=2300 \mathrm{~N}$,

- relative velocity of sliding movement $\mathrm{V}=0.132 \mathrm{~m} / \mathrm{min}$,

- the head's diameter $\phi 32 \mathrm{~mm}$,

- stem's length $1=130 \mathrm{~mm}$,

- stem fixing - flooding with Epidian with $\mathrm{Al}_{2} \mathrm{O}_{3}$ additive,

- lubricant: distilled water. 
The examples of friction pairs tested on simulator are shown in Table 1.

Table 1

\section{Tested friction pairs}

\begin{tabular}{|c|c|c|}
\hline & Cup & Endoprosthesis head \\
\hline 1. & UHMWPE & CoCrMo \\
\hline 2. & UHMWPE & Ti6Al4V \\
\hline 3. & UHMWPE & $\mathrm{Al}_{2} \mathrm{O}_{3}$ \\
\hline 4. & $\mathrm{Al}_{2} \mathrm{O}_{3}$ & $\mathrm{Al}_{2} \mathrm{O}_{3}$ \\
\hline 5. & $\mathrm{CoCrMo}$ & $\mathrm{CoCrMo}$ \\
\hline
\end{tabular}

Friction coefficient values were marked after 250000 cycles of the simulator's work, for each friction pair and were taken from the measurements of friction force and calculated on the dependence:

$$
\begin{gathered}
\mu=\frac{T_{\text {max }}}{P} \\
\mu=\frac{T_{\text {min }}}{P}
\end{gathered}
$$

where:

P - load force,

$\mathrm{T}_{\max }$ - maximal friction force of one cycle,

$\mathrm{T}_{\min }$ - minimal friction force of one cycle.

Figure 3 presents the obtained values of the friction coefficient for different friction pairs.

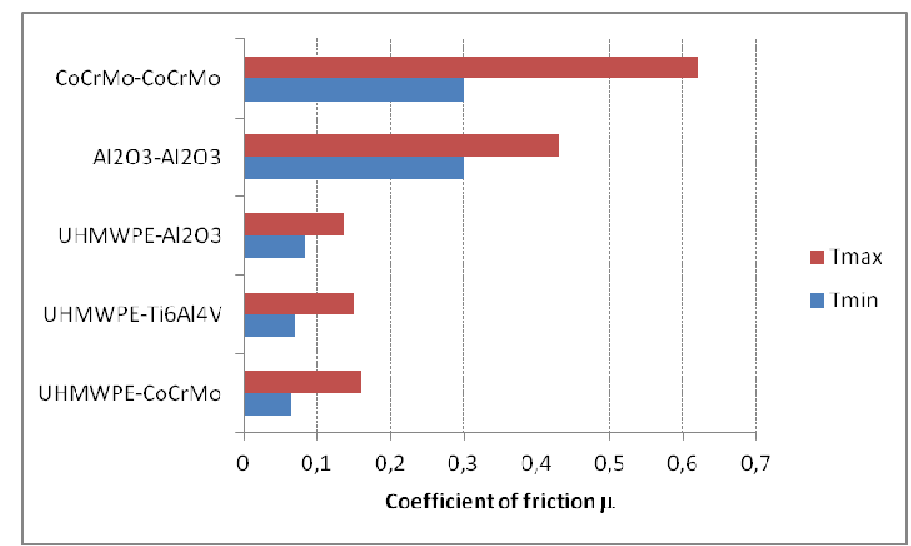

Fig. 3. Values of the friction coefficient for different friction pairs 
The results obtained on the simulator prove that friction resistance in hip joint endoprosthesis is much higher than the ones in a natural human hip joint. The values of friction coefficient for the tested pairs ranged:

- for $\mu_{\max }=0.137 \div 0.62$,

- for $\mu_{\min }=0.064 \div 0.3$.

The lowest friction coefficient values reached the pair: UHMWPE cup - $\mathrm{Al}_{2} \mathrm{O}_{3}$ head, because value $\mu_{\max }$ was 0.137 , and value $\mu_{\min }$ was 0.083 .

Slightly higher values of the friction coefficient were reached in the pair UHMWPE cup - CoCrMo head, and also in UHMWPE cup - Ti6Al4V head. These pairs reached similar values of $\mu_{\max }: 0.15$ and 0.16 , respectively. Also $\mu_{\min }$ values were similar as they reached $0.064 \div 0.07$.

The highest friction resistance was reached by the friction pairs $\mathrm{Al}_{2} \mathrm{O}_{3}-\mathrm{Al}_{2} \mathrm{O}_{3}$ and CoCrMo - CoCrMo. Reached values $\mu_{\max }$ ranged: 0.43 and 0.62 , respectively.

All the achieved results for similar pairs do not vary much between various authors $[6,7]$. It is important to mention that the way of mapping the mechanism of loads in endoprosthesis used in the simulator had a strong impact on the reached results of the friction resistance.

\section{Conclusions}

Lowest friction resistance occurred in the pair with polyethylene cup and $\mathrm{Al}_{2} \mathrm{O}_{3}$ head. Highest friction resistance was in pairs $\mathrm{Al}_{2} \mathrm{O}_{3}-\mathrm{Al}_{2} \mathrm{O}_{3}$ and $\mathrm{CoCrMo}-\mathrm{CoCrMo}$. Polyethylene cup decreases friction.

Considering all the reached results, it can be claimed that using a polyethylene cup causes friction decrease. Polyethylene cups are better at absorbing vibrations in the joint than the ones made of bio-ceramic or metal, which increase its durability. During the tests it was also observed that the method of lubrication significantly influences the friction resistance in the friction pair.

\section{References}

[1] Wierzcholski K, Miszczak A., Modele niestacjonarnego smarowania stawów człowieka z odkształcalną chrząstką w polu magnetycznym przy wspomaganej komputerowo optymalizacji hodowli tkanek kostnych w bioreaktorze, Akademia Morska w Gdyni, Gdynia 2006.

[2] Wierzcholski K., Pytko S., The parameters calculation method for biobearing lubricated with non-Newtonian lubricants, Tribologia 1993, 1/93(127), 9-12.

[3] Jaworek K., Jędrzejewski B., Kinetyka stawu biodrowego i kolanowego podczas normalnego chodu człowieka. Problemy niekonwencjonalnych układów łożyskowych, Wydawnictwo Politechniki Warszawskiej, Warszawa 1995.

[4] Gierzyńska-Dolna M., Wieczorek A., Lacki P., Procesy tribologiczne a powikłania infekcyjne w alloplastyce stawu biodrowego, Chirurgia Narządów Ruchu i Ortopedia Polska 1999, XIII, 2, 98-103. 
[5] Gierzyńska-Dolna M., Więckowski W., Wpływ procesów tribologicznych na niepowodzenia w alloplastyce stawu biodrowego. Materiały II Sympozjum Biomechanika w Implantologii, Katowice 1999, 42-48.

[6] Optymalizacja doboru materiałów i obróbki powierzchniowej niektórych endoprotez narządów ruchu człowieka w oparciu o badania tarciowo-zużyciowe. Praca zbiorowa pod red. M. Gierzyńskiej-Dolnej, Sprawozdanie z projektu badawczego Nr 7 T08C 03809, 1998.

[7] Hall R.M., Unsworth A., Friction in hip prostheses, Biomaterials 1997, 18, 1017-1026. 